\title{
Сучасний спортивний менеджер як об'єкт наукового аналізу
}

\author{
Марина Корольова \\ Світлана Стадник \\ Анастасія Бондар \\ Ірина Петренко
}

Харківська державна академія фозичної культури, Харків, Україна

Mета: розробити системно-структурну модель сучасного спортивного менеджера на основі визначення об'єктивних та суб'єктивних характеристик його діяльності.

Матеріал і методи: проведений теоретичний аналіз і систематизація літературних джерел за темою дослідження дав змогу з'ясувати проблемне поле діяльності спортивного менеджера у сучасних умовах. Аналіз документальних матеріалів дозволив охарактеризувати систему правової регламентації праці спортивного менеджера, а також компетенції, завдання, функції, результати його діяльності. Застосування методу системного аналізудозволило обгрунтуватиоб'єктивніта суб'єктивніхарактеристикидіяльностіспортивногоменеджера. Зметоювизначенняіндивідуальнихта професійних якостей спортивного менеджера, а такожякостей, які негативно впливають на ефективність його професійної діяльності було проведено опитування серед 40 респондентів: керівників фрізкультурно-спортивних організацій та серед студентів кафедри менеджменту фрізичної культури ХДАФК.

Результати: проаналізовано нормативно-правову складову підготовки спортивних менеджерів. Розроблено системно-структурну модель, яка складається із мети та двох частин: об'єктивних та суб'єктивних характеристикдіяльності сучасного спортивного менеджера. Визначено мету діяльності спортивного менеджера - забезпечити ефективне функціонування фрізкультурно-спортивної організації. З'ясовано, що до об'єктивних характеристик діяльності сучасного спортивного менеджера відносяться: компетентності, завдання та функції спортивного менеджера. До суб'єктивниххарактеристиквідносяться:професійно-рольовіхарактеристики, профресійноважливіякостітанегативні якості.

Висновки: з'ясовано, що спортивний менеджер - це унікальна сучасна професія, яка потребує постійного вдосконалення, розвитку практичних навичок, швидкого реагування на всі зміни, що відбуваються, підвищеного інтересу до самоосвіти, високого рівня самодисципліни. Саме профресіоналізм, відповідальність, ініціатива й заповзятливість менеджерів здатні у будь-якій складній ситуації забезпечити фрізкультурно-спортивній організації успіх і прибуток, високу есрективність реалізованої практичноїдіяльності.

Ключові слова: спортивний менеджер, системно-структурна модель, компетенції, завдання, фрункції, професійнорольові характеристики, професійно важливі якості.

\section{Вступ}

Наш бурхливий час вимагає енергійних ібагатогранних професій. До таких належить і професія менеджер. Що вона собою представляє і як домогтися успіху в менеджменті? Сучасних визначень поняття «менеджмент» дуже багато. Найчастіше менеджмент розглядається як мистецтво управління, сукупність функцій, орієнтованих на ефективне використання людських, матеріальних та фінансових ресурсів задля досягнення цілей організації. Доречним буде вислів Пітера Ф. Друкера: «Менеджмент це особливий вид діяльності, що перетворює неорганізований натовп в ефективну, цілеспрямовану і продуктивну групу» [8].

Успіх організації ми пов'язуємо з ім'ям тадіяльністю менеджерів. Сучасний менеджер виступає в декількох ролях, які підкреслюють актуальність та значимість цієї професії. По-перше, менеджер - це управлінець, наділений владою, що керує колективом людей. По-друге, це лідер, спроможний вести за собою підлеглих, використовуючи свій авторитет, високий професіоналізм, позитивні емоції. По-третє, це людина, яка має комунікативні здібності, постійно встановлює контакти зі споживачами, партнерами і владою. По-четверте, це людина, яка наділена стратегічним мисленням, може формувати цілі, основні види діяльності, визначати власні переваги та напрямки їхвикористання. По-п'яте, це новатор, який розуміє роль науки в сучасних умовах, вміє оцінити і без зволікання впровадити той або інший винахід чи технологію. По-шосте, це людина, яка має високий рівень культури, чесна, рішуча за характером і водночас розважлива. Сьоме, це вихователь, котрий володіє високими моральними якостями, спроможний створити колектив і спрямувати його розвиток, сформувати організаційну культуру організації [4].

Проведений аналіз літературних джерел свідчить про науковий інтерес вітчизняних та зарубіжних авторів до діяльності менеджерів у сорері фізичної культури та спорту $[2,7,12,13]$. Авторами робіт аргументовано представлено особливості діяльності працівників органів управління фізичною культурою та спортом, директорів спортивних шкіл, училищ фізичної культури, спортивних клубів, організаторів фрізкультурно-спортивних заходів тощо. Однак у ході аналізу літератури було виявлено, що до вивчення діяльності менеджера у сфері фрізичної культури та спорту не застосовувався системний підхід. Актуальність даної роботи обумовлюється необхідністю наукового обґрунтування діяльності менеджера з певним комплексом завдань, функцій, знань, умінь, навичок та якостей у сучасних умовах функціонування фрізкультурно-спортивних організацій. 


\section{СЛОБОЖАНСЬКИЙ НАУКОВО-СПОРТИВНИЙ ВІСНИК:}

\section{Матеріали XIX Міжнародної науково-практичної конференції «Фізична культура, спорт і здоров'я: стан, проблеми та}

Мета дослідження: розробити системно-структурну модель сучасного спортивного менеджера на основі визначення об'єктивних та суб'єктивних характеристик його діяльності.

\section{Матеріал і методидослідження}

Проведений теоретичний аналіз і систематизація літературних джерел за темою дослідження дав змогу з'ясувати проблемне поле діяльності спортивного менеджера у сучасних умовах. Аналіз документальних матеріалів дозволив охарактеризувати систему правової регламентації праці спортивного менеджера, а також компетенції, завдання, функції, результати його діяльності. Застосування методу системного аналізу дозволило обґрунтувати об'єктивні та суб'єктивні характеристики діяльності спортивного менеджера. 3 метою визначення індивідуальних та професійних якостей спортивного менеджера, а також якостей, які негативно впливають на ефрективність його професійної діяльності було проведено опитування серед 40 респондентів: керівників фрізкультурно-спортивних організацій та серед студентів кафедри менеджменту фрізичної культури ХДАФК.

\section{Результати дослідження}

У ході нашого дослідження насамперед було проаналізовано нормативно-правову складову підготовки спортивних менеджерів. Було визначено, що базовими нормативно-правовими актами, на основі яких здійснюється підготовка фрахівців у сфрері фрізичної культури та спорту є Закон України «Про вищу освіту», Закон України «Про освіту», Закон України «Про фрізичну культуру спорт», Постанова Кабінету Міністрів України від 23 листопада 2011 р. № 1341 «Про затвердження Національної рамки кваліфікацій», Постанова Кабінету Міністрів від29 квітня 2015 р. № 266 «Про затвердження переліку галузей знань і спеціальностей, за якими здійснюється підготовка здобувачів вищої освіти», Національний класифікатор України: «Класифрікатор професій» ДК 003:2010., Стандарт вищої освіти за спеціальністю 017 «Фізична культура і спорт» для першого (бакалаврського) рівня вищої освіти та освітньо-професійна програма.

Особливістю підготовки бакалаврів за спеціалізацією «Менеджмент у спортивній діяльності», є системний та комплексний підхід до напрямків, методів, засобів підготовки менеджерів (керівників) сфери фізичної культури та спорту, застосування сучасних технологій підготовки менеджерів та контролю за ефективністю їх діяльністю. Високий (достатній) рівень практичної підготовки забезпечується стажуванням здобувачів вищої освіти на відповідних базах практик (департаментах у справах сім'ї, молоді та спорту, управліннях з питань фрізичної культури та спорту, федераціях з видів спорту, дитячо-юнацьких спортивних школах, школах олімпійського резерву та ін.) із залученням провідних фрахівців галузі, які мають досвід роботи на керівних посадах.

У результаті проведеного дослідження нами було розроблено системно-структурну модель, яка складається із мети та двох частин: об'єктивних та суб'єктивних характеристик діяльності сучасного спортивного менеджера. Мета - забезпечити ефективне функціонування фрізкультурно-спортивної організації. До об'єктивних характеристик відносяться: компетентності, завдання та функції спортивного менеджера. До суб'єктивних характеристик відносяться: професійно-рольові характеристики, професійно важливі якості та негативні якості.

Інтегральною компетентністю для спортивного менеджера є здатність розв'язувати складні спеціалізовані завдання та практичні проблеми у сфері фрізичної культури і спорту, що передбачає застосування теорій та методів наук з фрізичного виховання і спорту, а також характеризується комплексністю та невизначеністю умов. Дозагальних компетентностей ми відносимо: здатність працювати у команді, використовувати інформаційні та комунікаційні технології, застосовувати знання у практичних ситуаціях тощо. До спеціальних (фахових, предметних) компетенцій належать: здатність застосовувати сучасні технології управління суб'єктами сорери фрізичної культури і спорту; здатність до організації оздоровчо-рекреаційної рухової активності різних груп населення; здатність проводити тренування та супроводження участі спортсменів у змаганнях тощо.

У розробленій нами моделі представлено 5 основних завдань діяльності сучасного спортивного менеджера:

1) визначення стратегії розвитку фрізкультурноспортивної організації у сучасних умовах функціонування;

2) забезпечення раціональної фінансовогосподарської діяльності фрізкультурно-спортивної організації;

3) здійснення PR-діяльності фрізкультурно-спортивної організації;

4) управління персоналом фрізкультурно-спортивної організації;

5) постійне вдосконалення своєї професійної діяльності або самоменеджмент.

У рамках цих завдань кожний менеджер вирішує основні та спеціальні фрункції управління. До основних фрункцій відносяться: планування, організація, мотивація, контроль та прийняття управлінських рішень. До спеціальних функцій діяльності сучасного спортивного менеджера ми відносимо:

$\checkmark$ збереження і зміцнення матеріально-технічної бази;

$\checkmark$ пошук додаткових джерел фінансування;

$\checkmark$ впровадження інноваційних методів та технологій

$\checkmark$ забезпечення дотримання законності, вимог охорони праці;

$\checkmark$ розпорядження фінансовими коштамиорганізації;

$\checkmark$ укладання та виконаннядоговорів;

$\checkmark$ представництво інтересів організації;

$\checkmark$ організація науково-методичного забезпечення;

$\checkmark$ організація обслуговування колективу;

$\checkmark$ розробка бренд-стратегії організації;

$\checkmark$ організація маркетингової діяльності фрізкультурноспортивної організації;

$\checkmark$ самовдосконалення і самореалізація та ін.

До професійно-рольових характеристик відносяться знання, уміння та навички, які необхідні спортивному менеджеру для реалізації загальних і спеціальних функкцій управління. Спортивний менеджер повинен знати: основи психології, економіки, правове регулювання, клубний менеджмент, спортивний маркетинг, менеджмент персоналу, стратегічний менеджмент, менеджмент спортивних заходів тощо. Уміти: організовувати спортивні змагання; вибирати ефективні методи управління; оцінювати ефективність діяльності організації; прогнозувати майбутне 


\section{СЛОБОЖАНСЬКИЙ НАУКОВО-СПОРТИВНИЙ ВІСНИК:}

\section{Матеріали XIX Міжнародної науково-практичної конференції «Фізична культура, спорт і здоров'я: стан, проблеми та перспективи»}

організації; розбиратися в людях; фоормувати команду

Менеджер повинен володіти ще й необхідними для здійснення керівництва навичками, які ми умовно об'єднали у 3 групи: аналітичні, комунікативні та адміністративні. До адміністративних ми відносимо володіння персональним комп'ютером, складання планів, звітів тощо. До комунікативних навичок відносяться, на нашу думку, ефективна взаємодія з людьми, вибір ефективних каналів комунікації, володіння іноземними мовами, вміння вести ділові переговори та бесіди. До аналітичних навичок належать: вміння аналізувати інформацію, установлювати взаємозв'язки, передбачати труднощітощо.

Як показало опитування, найбільш важливими для сучасного спортивного менеджера $€$ такі індивідуальні та професійні якості, як організаторські здібності $(87,5 \%)$, відповідальність (75\%), ініціативність $(67,5 \%)$, високі моральні якості $(62,5 \%)$, активність $(55 \%)$, дисциплінованість $(45 \%)$, вимогливість до себе $(37,5 \%)$, вміння переконувати (25\%) і нервово-психічна стійкість (17,5\%), вимогливість до своїх підлеглих (95\%), об'єктивність оцінки праці $(87,5 \%)$, володіння загальними та спеціальними знаннями (75\%), комунікативні якості (95\%), авторитетність $(87,5 \%)$.

До професійно важливих якостей відносяться не тільки індивідуальні і профресійні якості, але й внутрішні стимули, що дозволяють менеджеру не тільки долати труднощі в роботі, ставити і досягати нові цілі, але й самореалізовуватися, саморозвиватися. До них відносяться: любов до спорту (95\%); стійка професійна орієнтація (87,5\%); вірність своїм обов'язкам (75\%); почуття відповідальності за своїх підлеглих $(62,5 \%)$; підтримка іміджу своєї організації (55\%); прагнення до розвитку своїх профресійних знань, умінь та навичок (45\%); оволодіння інноваційними підходами і технологіями діяльності (37,5\%).

Завершують розділ суб'єктивних характеристик розробленої нами моделі якості, які негативно впливають на ефрективність професійної діяльності менеджера: недостатній профресійний рівень (75\%), консерватизм $(67,5 \%)$, нервово-психічна нестійкість (55\%); безвідповідальність (45\%), конфрліктність (45\%), завищена і занижена самооцінки (25\%). Безумовно, перераховані якості негативно впливають на процес прийняття управлінських рішень, організацію фрінансово-господарської роботи, керівництво діяльністю організації в цілому.

\section{Висновки /Дискусія}

Аналіз сучасної вітчизняної науково-методичної лі- тератури дозволив визначити напрямки наукових досліджень щодо діяльності спортивного менеджера:

1) досвід підготовки спортивних менеджерів у зарубіжних країнах (М.В. Дутчак [2], О.М. Ельбрехт [4], Т.Г. Дерека, В.М. Туманова [1], С.В. Криштанович [5] та ін.). Аналіз літературних джерел з даного напрямку свідчить, що у різних країнах світу система підготовки спортивних менеджерів у вищих навчальних закладах бере свій початок з другої половини 80-х років XX століття. Лідером в $\Theta_{\mathrm{B}-}$ ропі з підготовки менеджерів для сфери фрізичної культури і спорту вважаєтьсяВеликобританія;

2) система підготовки спортивних менеджерів в Україні (С.О. Стадник, І.І. Приходько [8], В.Е. Куделко, А.М. Куделко [6] та ін.). У ході аналізу літературних джерел 3 цього напрямку визначено, що система підготовки спортивних менеджерів в Україні забезпечується спеціалізованими закладами вищої освіти спортивного профілю: Національний університет фізичного виховання і спорту та Харківська державна академія фрізичної культури;

3) особливості та зміст діяльності спортивного менеджера знаходимо у працях Л.Я. Чеховської [10], І.І. Перевєрзіна [7], В.С. Шеріна [11], Р. Тягура [9] та ін.;

4) профресійна компетентність та особистість спортивного менеджера є об'єктом наукових досліджень Ю.В. Дутчака [3], Karen Danylchuk [12] та ін.

Отже, спортивний менеджер - це унікальна сучасна професія, яка вимагає від особистості управлінця постійного вдосконалення, набуття практичних навичок швидкого реагування на зміни, що відбуваються в організації і у зовнішньому середовищі, підвищеного інтересу до самоосвіти, високого рівню самодисципліни. Саме професіоналізм, відповідальність, ініціатива й заповзятливість менеджерів здатні у будь-якій ситуації забезпечити фрізкультурно-спортивній організації успіх, високу ефективність реалізованої практичної діяльності і досягнення поставлених цілей.

Розроблена нами системно-структурна модель спортивного менеджера розкриває мету, завдання, фрункції, знання, уміння та навички, індивідуальні та професійні якості, які необхідні керівнику для досягнення поставленої стратегічної мети. Особливість моделі полягає у тому, що у ній представлено співвідношення знань, умінь, навичок, які забезпечують ефективність реалізації кожної фрункції менеджменту у рамках поставлених завдань та мети.

Перспективи подальших досліджень у даному напрямку стосуються вивчення ринку праці спортивнихменеджерів в Україні, зокрема потреби і попиту на фахівців цієї профресії.

Конфлікт інтересів. Автори заявляють, що немає конфлікту інтересів, який може сприйматися таким, що може нанести шкоду неупередженості статті.

Джерела фінансування. Ця стаття не отримала фінансової підтримки від державної, громадської або комерційної організації.

\section{Список посилань}

1. Дерека, Т. Г., Туманова, В. М. (2017), «Сучасний зарубіжний досвід професійної підготовки фахівців фрізичного виховання для України», Науковий часопис Національного педагогічного університету імені М. П. Драгоманова. Серія 15: Науково-педагогічні проблеми фрізичної культури (фрізична культура і спорт), Вип. 10, С. 32-35. URL: http://nbuv.gov.ua/UJRN/Nchnpu 015 2017 10 10 2. Дутчак, М. В. (2009), "Підготовка фахівців з менеджменту і управління спортом для всіх у зарубіжних країнах". Педагогіка, психологія та медико-біологічні проблеми з фрізичного виховання і спорту, №3, С. $43-48$.

3. Дутчак, Ю. В. (2013), Особистісні детермінанти організованості спортивного менеджера як суб'єкта управлінської діяльності: автореф. дис. канд. наук фіз. вих., Львів, 20 с.

4. Ельбрехт, О. (2012), “Модернізація змісту підготовки менеджерів: глобальні тенденції та національна специфіка”, Молодь і ринок, №5 (88), C. 5 - 8. 


\section{Матеріали XIX Міжнародної науково-практичної конференції «Фізична культура, спорт і здоров'я: стан, проблеми та}

5. Криштанович, С.В.(2017), “Формування у майбутніх менеджерів фрізичної культури і спорту готовності до професійної ді яльності”, Молодий вчений, № 3, C. 414-417. URL: http://nbuv.gov.ua/UJRN/molv_2017_3_99

6. Куделко, В. Е., Куделко, А. М. (2014), “Конкурентоспроможність освітньої послуги за напрямом підготовки «Менеджмент у спорті» на освітянському ринку України”, Педагогіка, психологія та медико-біологічні проблеми фізичного виховання і спорту, №4 C. 22-26. URL: https://cyberleninka.ru/article/n/konkurentosposobnost-obrazovatelnoy-uslugi-po-napravleniyu-podgotovki-menedzhmentv- sporte-na-rinke-obrazovatelnyh-uslug-ukrainy/viewer

7. Переверзин, И.И. (2003), “Современный российский спортивный менеджер и модель его подготовки”, Теория и практика физической культуры, №5. С. 57- 60.

8. Стадник, С. А., Приходько, И. И. (2013), “Совершенствование подготовки менеджеров в сфере физической культуры и спота в Украине”, Педагогіка, психологія та медико-біологічні проблеми з фрізичного виховання і спорту, №9, С. 91 - 95

9. Тягур, Р. (2013), “Особливості управлінської праці у сфері фізичного виховання і спорту”, Вісник Прикарпатського універси-тету, Вип. 18, С. $129-137$

10. Чеховська, Л. Я. (2002), “Теоретичні основи управлінської праці фрізкультурного керівника”, Проблеми активізації рекреаційнооздоровчої діяльності населення : матеріали III Міжрегіональної науково-практичної конференції, Львів, С. 51 - 54

11. Шерин, В. С. (2011), “Модель формирования компетентности управленческой деятельности специалиста по физической культуре и спорту", Вестник Томского государственного университета, № 347, С. 147 - 150.

12. Danylchuk, K. (2011), "Internationalizing Ourselves: Realities, Opportunities, and Challenges", Journal of Sport Management, Volume 25, Issue 1, pp 1-10. DOI: https://doi.org/10.1123/jsm.25.1.1

13. Mahony, F. Daniel (2008), “No One Can Whistle a Symphony: Working Together for Sport Management's Future”, Journal of Sport Management, Volume 22, Issue 1, pp 1-10. DOI: https://doi.org/10.1123/jsm.22.1.1

Стаття надійшла до редакції: 11.11.2019 p

Опубліковано: 30.12.2019 р.

Аннотация. Марина Королёва, Светлана Стадник, Анастасия Бондарь, Ирина Петренко. Современный спортивный менеджер как объект научного анализа. Цель: разработать системно-структурную модель современного спортивного менеджера на основе определения объективных и субъективных характеристик его деятельности. Материал и методы: проведеный теоретический анализ и систематизация литературных источников по теме исследования позволил выяснить проблемное поле деятельности спортивного менеджера в современных условиях. Анализ документальных материалов позволил охарактеризовать систему правовой регламентации труда спортивного менеджера, а также компетенции, задачи, фрунции, результаты его деятельности. Применение метода системного анализа позволило обосновать объективные и субъективные характеристики деятельности спортивного менеджера. С целью определения индивидуальных и профрессиональных качеств спортивного менеджера, а также качеств, которые негативно влияют на эфрфективность его профессиональной деятельности был проведен опрос среди 40 респондентов: руководителей фризкультурно-спортивных организаций и среди студентов кафедры менеджмента фризической культуры ХГАФК. Результаты: проанализирована нормативно-правовая составляющая подготовки спортивных менеджеров. Разработана системно- структурная модель, которая состоит из иели и двух частей: объективных и субъективных характеристик деятельности современного спортивного менеджера. Определены цели деятельности спортивного менеджера - обеспечить эффрективное ффункционирование физкультурно-спортивной организации. Установлено, что к объективным характеристикам деятельности современного спортивного менеджера относятся: компетентности, задачи и функции спортивного менеджера. К субъективным характеристикам относятся: профессионально-ролевые характеристики, профессионально важные качества и отрицательные качества. Выводы: выяснено, что спортивный менеджер - это уникальная современная профрессия, которая требует постоянного совершенствования, развития практических навыков, быстрой реакции на все происходящие изменения, повышенного интереса к самообразованию, высокого уровня самодисциплины. Именно профрессионализм, ответственность, инициатива и предприимчивость менеджеров способны в любой сложной ситуации обеспечить физкультурно-спортивной организации успех и прибыль, высокую эфрфективность реализуемой практической деятельности.

Ключевые слова: спортивный менеджер, системно-структурная модель, компетенции, задачи, функции, профрессионально- ролевые характеристики, профессионально важные качества.

Abstract. Maryna Korolova, Svitlana Stadnik, Anastasia Bondar, Irina Petrenko. Modern sports manager as an object of scientific analysis. Purpose: to develop a system-structural model of a modern sports manager on the basis of determining the objective and subjective characteristics of his activities. Material and methods: the theoretical analysis and systematization of literary sources on the topic of research made it possible to determine the problematic field of the sports manager's activity in modern conditions. The analysis of documentary materials made it possible to characterize the system of legal regulation of the work of a sports manager, as well as competencies, tasks, functions, and the results of his activities. The application of the method of system analysis made it possible to justify the objective and subjective characteristics of the sports manager. In order to determine the individual and professional qualities of a sports manager, as well as qualities that negatively affect the effectiveness of his professional activity, a survey was conducted among 40 respondents: heads of physical education and sports organizations and among students of the Department of Physical Culture Management of KSAPC. Results: the regulatory component of the training of sports managers is analyzed. A system-structural model has been developed, which consists of a goal and two parts: objective and subjective characteristics of the activities of a modern sports manager. The goals of the activities of the sports manager are determined - to ensure the effective functioning of the sports organization. It is established that the objective characteristics of the activities of a modern sports manager include: competencies, tasks and functions of a sports manager. Subjective characteristics include: professional-role characteristics, professionally important qualities and negative qualities. Conclusions: it turned out that the sports manager is a unique modern profession, which requires continuous improvement, development of practical skills, quick reaction to all changes that take place, increased interest in self-education, and a high level of self-discipline. It is the professionalism, responsibility, initiative and enterprise of managers in any difficult situation that can ensure the physical culture and sports organization success and profit, high efficiency of implemented practical activities.

Keywords: sports manager, system-structural model, competencies, tasks, functions, professional-role characteristics, professionally important qualities. 


\section{СЛОБОЖАНСЬКИЙ НАУКОВО-СПОРТИВНИЙ ВІСНИК:}

\section{Матеріали XIX Міжнародної науково-практичної конференції «Фізична культура, спорт і здоров'я: стан, проблеми та перспективи»}

\section{References}

1. Dereka, T. H., Tumanova, V. M. (2017), "Modern foreign experience of professional training of physical education specialists for Ukraine", Naukovyi chasopys Natsionalnoho pedahohichnoho universytetu imeni M. P. Drahomanova. Seriia 15: Naukovo-pedahohichni problemy fizychnoi kultury (fizychna kultura i sport), Vyp.10, pp. 32-35. (in Ukr)

2. Dutchak, M. V. (2009), "Training of specialists in management and management of sports for all in foreign countries". Pedahohika, psykholohiia ta medyko-biolohichni problemy z fizychnoho vykhovannia i sportu, No. 3, pp. 43 - 48. (in Ukr).

3. Dutchak, Yu. V. (2013), Osobystisni determinanty orhanizovanosti sportyvnoho menedzhera yak subiekta upravlinskoi diialnosti

[Personal determinants of the organization of a sports manager as a subject of managerial activity]: avtoref. dys. kand. nauk fiz. vykh., Lviv, 20

p. (in Ukr)

4. Elbrekht, O. (2012), "Modernizing the content of manager training: global trends and national specificity", Molod i rynok, No. 5 (88), pp.

5-8. (in Ukr)

5. Kryshtanovych, S. V. (2017), "Formation in future managers of physical culture and sports readiness for professional activity", Molodyi vchenyi, No. 3, pp. 414-417. (in Ukr).

6. Kudelko, V. E., Kudelko, A. M. (2014), "Competitiveness of educational service in the field of training "Management in Sport" in the educational market of Ukraine", Pedahohika, psykholohiia ta medyko-biolohichni problemy fizychnoho vykhovannia i sportu, No. 4, pp. 2226. (in Ukr).

7. Pereverzin, I.I. (2003), "Modern Russian sports manager and training model”, Teoriya i praktika fizicheskoy kulturyi, No. 5. pp. 57- 60. (in. Russ).

8. Stadnik, S. A., Prihodko, I. I. (2013), "Improving the training of managers in the field of physical education and sports in Ukraine", Pedahohika, psykholohiia ta medyko-biolohichni problemy fizychnoho vykhovannia i sportu, No. 9, pp. 91 - 95. (in. Russ).

9. Tiahur, R. (2013), "Features of management work in the field of physical education and sports", Visnyk Prykarpatskoho universytetu, Vyp. 18, pp. $129-137$. (in Ukr).

10. Chekhovska, L. Ya. (2002), "Theoretical bases of managerial work of the physical culture leader", Problemy aktyvizatsii rekreatsiinoozdorovchoi diialnosti naselennia [Problems of activation of recreational and recreational activity of the population]: materialy III Mizhrehionalnoi naukovo-praktychnoi konferentsii, Lviv, pp. 51 - 54. (in Ukr).

11. Sherin, V. S. (2011), "A model for the formation of the competence of the managerial activity of a specialist in physical education and sports", Vestnik Tomskogo gosudarstvennogo universiteta, No. 347, pp. 147 - 150. (in. Russ).

12. Danylchuk, K. (2011), "Internationalizing Ourselves: Realities, Opportunities, and Challenges", Journal of Sport Management, Volume 25, Issue 1, pp 1-10. DOI: https://doi.org/10.1123/jsm.25.1.1

13. Mahony, F. Daniel (2008), "No One Can Whistle a Symphony: Working Together for Sport Management's Future", Journal of Sport Management, Volume 22, Issue 1, pp 1-10. DOI: https://doi.org/10.1123/jsm.22.1.1

Received: 11.11.2019

Published: 30.12 .201

\section{Відомості про авторів / Information about the Authors}

\footnotetext{
Корольова Марина Вікторівна: кандидат юридичних наук, Харківська державна академія фрізичної культури: вул. Клочківська 99, м. Харків, 61058, Україна.

Королёва Марина Викторовна: кандидат юридических наук, Харьковская государственная академия фризической культуры: ул. Клочковская 99, г. Харьков, 61058, Украина.

Maryna Korolova: Candidate of Juridical Sciences (Ph.D), Kharkiv State Academy of Physical Culture: 99 Klochkivska Str., Kharkiv, 61058, Ukraine.

E-mail: m.korolova@khdafk.com

ORCID.ORG/0003-2931-2190

Стадник Світлана Олександрівна:к. фріз.вих., Харківська державна академія фрізичної культури: вул. Клочківська 99, м.Харків,61058, Україна.

Стадник Светлана Александровна: к. физ. восп., Харьковская государственная академия фризической культуры: ул. Клочков- ская 99, г. Харьков, 61058, Украина.

Svitlana Stadnyk: PhD (Physikal Education and Srort), Kharkiv State Academy of Physikal Cuiture: Klochkivska str. 99, Kharkiv, 61058, Ukraine.

E-mail: svetlanastadnik87@gmail.com
}

ORCID.ORG/0000-0001-6694-1098

Петренко Ірина Вікторівна: к. фріз. вих.; Харківська державна академія фрізичної культури: вул. Клочківська, 99, м. Харків, 61058, Україна.

Петренко Ирина Викторовна: к. физ. восп.; Харьковская государственная академия физической культуры: ул. Клочковская, 99, г. Харьков, Украина

Iryna Petrenko: PhD (Physical Education and Sport); Kharkiv State Academy of Physical Culture: Klochkivska str., 99, Kharkiv, 61058 Ukraine.

E-mail: ivpetrenko18@ukr.net

ORCID.ORG/0000-0003-4252-1130

Бондар Анастасія Сергіївна: к. фріз. вих., доцент; Харківська державна академія фрізичної культури: вул. Клочківська, 99, м.Харків, 61058, Україна.

Бондарь Анастасия Сергеевна: к. фриз. восп., доцент; Харьковская государственная академия фризической культуры: ул. Клочковская, 99, г. Харьков, Украина.

Anastasia Bondar: PhD (Physical Education and sport); Kharkiv State Academy of Physical Culture: Klochkivska str., 99, Kharkiv, 61058, Ukraine.

E-mail: anastasiabond1@ukr.net

ORCID.ORG/0000-0002-2816-4985 